\title{
Geospatial technique for characterization, evaluation and management of land resources of Shegaon watershed, district Chandrapur, Maharashtra
}

\author{
S. S. Potdar ${ }^{*}$, V. V. Gabhane ${ }^{2}$, Rajeev Srivastava ${ }^{3}$, V. K. Kharche ${ }^{2}$, R. A. Nasre ${ }^{3}$ and M. \\ S. S. Nagaraju ${ }^{3}$ \\ ${ }^{1}$ Anand Niketan College of Agriculture, Anandwan, Warora, Chandrapur-442914, India \\ ${ }^{2}$ Dr. Panjabrao Deshmukh Krishi Vidyapeeth Akola- 444104, India \\ ${ }^{3}$ ICAR-National Bureau of Soil Survey and Land Use Planning, Nagpur - 440033, India
}

\begin{abstract}
Characterization, evaluation and management of land resources in Shegaon watershed of Chandrapur district of Maharashtra were carried out using IRS-LISS-IV and LISS-III data and GIS coupled with ground truth verification. Six major landform units viz. isolated mound, subdued plateau, upper pediment, lower pediment, upper plain and lower plain were identified and delineated. Based on image characteristics, the major land use/ land cover identified were cultivated land, wasteland with and without scrub, habitation and water bodies. Cultivated land is again delineated into single and double crop based on temporal data. Seven soil series were tentatively identified and mapped as series and complex with phases on 1:12, 500 scales based on landform-soil relationship. Soils occurring on moderately sloping (8-15\%) isolated mound were very shallow, well drained (Typic Ustorthents) whereas soils on subdued plateau were shallow belong to Lithic and Typic Haplustepts sub-groups. Typic and Vertic Haplusterts in complex were identified on gently sloping (1-3\%) upper pediment. Soils of lower pediments were deep Typic Haplusterts. Upper plain lands of the watershed had very deep, (Typic Haplusterts) whereas soils of lower plains were Sodic Haplusterts. These soils were grouped IIIs, IIIsf, IVs, IVf, IVsf and VIs land capability subclasses and 2 st, $3 \mathrm{st}, 4 \mathrm{~s}$ and $4 \mathrm{st}$ land irrigability sub-classes. The soil suitability class indicated that very shallow to shallow soils are potentially suitable (N1) to marginally suitable while deep to very deep soils are marginally to moderately suitable to paddy, cotton, soybean, sorghum, red gram and chickpea crops. Suitable conservation measures and interventions have been suggested to improve the productivity of these soils.
\end{abstract}

Key words: Geospatial technique; land capability; suitability for crops.

\section{Introduction}

Sustainable management of land resources is essential for food security, maintenance of environment and betterment of the society. Soils are an integral part of the landscape and

\footnotetext{
*Corresponding author (Email : suhaspotdar.anca@gmail.com)
} 
their characteristics are largely governed by landform on which they are developed (Sharma et al. 1999). Systematic study of morphology and taxonomy of soils provides information on nature and type of soils, their constraints, potentials, capabilities and their suitability for various uses (Sehgal 1996). Precise scientific information on characteristics, potential, limitations and management needs of different soil is indispensible for proper utilization of land resources to maintain the soil productivity and to meet the demands of the future. Rational utilization of land resources can be achieved by optimizing its use, ensuring its sustainable use.

Remote sensing data provide multi-spectral, multi-temporal and multi-sensor information of the earth's surface and offers greater accuracy, economy and is more efficient in data collection and mapping of land resources than the conventional method (Venkatratnam 1981; Kasturirangan et al. 1996). Several studies have initiated to characterize, evaluate and management of land resources at large scale using advanced tools (Srivastava and Saxena 2004; Shukla et al. 2009). Therefore, in the present study an attempt has been made to characterize, evaluate and map the land resources of Shegaon watershed in Warora tahsil, district Chandrapur (MS) using IRS- P6 (Resourcesat-1) LISS-IV and LISS-III data in GIS.

\section{Materials and Methods}

Shegaon watershed in Warora tahsil of Chandrapur district of Maharashtra located between $20^{\circ} 18^{\prime} \mathrm{N}$ to $20^{\circ} 22^{\prime}$ latitude and $79^{\circ} 05^{\prime}$ to $79^{\circ} 10^{\prime} \mathrm{E}$ longitude with an the area of 2249.88 ha. The study area is covered by the Survey of India Toposheet No.55P/3. Geologically the area mainly occupied by the Deccan basalts followed by sandstone/limestone of Lameta group of cretaceous period. The watershed area was divided into six major landform units, viz., isolated mound, subdued plateau, upper pediment, lower pediment, upper plain and lower plain. The mean elevation of area varies from 220 to $260 \mathrm{~m}$ above mean sea level (MSL) associated with moderately sloping (8-15\%), gently sloping (3-8\%), very gently sloping (1-3\%), and nearly level (0 - 1\%) sloping lands. The climate of the area is subtropical; dry sub-humid with ustic soil moisture regime and hyperthemic soil temperature regime. The average rainfall is $1200 \mathrm{~mm}$ which is received mostly from south-west monsoon. The natural vegetation comprises dry deciduous mixed trees, and grasses. The trees are teak (Tectona grandis), khair (Acacia catechu), neem (Azardirachta indica), tendu (Diospyros melanoxylon), behra (Terminalia bellirica), babul (Acacia arabica), shivan (Gmelina arborea), palas (Butea monosperma), etc. and the grasses are dub (Impara cuplinatrica), kural (Heteropogon contortus), kundu (Schema pilosum) etc. A large 
percentage of cultivated land is mainly under kharif crops such as paddy (Orizae sativa), pigeon pea (Cajanus cajan), cotton (Gossypium spp.), soybean (Glycine max) and maize (Zea mays) while the main rabi crops are wheat (Triticum spp.), linseed (Linum usitatisimum), chickpea (Cicer arentium), vegetables and few mango orchards are also scattered and grown under irrigation or stored moisture.

Digital data of IRS-P6 LISS-IV (February 2010) along with LISS-III (October 2008) was geocoded using ArcGIS 10.2. The toposheet was used to prepare base map for different landforms, generation of slope and drainage for field survey and ground truth collection. The land use/ land cover map generated from the, the visual interpretation of geocoded satellite data based on tone, texture, pattern, shape and size (Lillesand and Kiefer 2002). The landforms, slope and land use/ land cover were considered for depicting the soil variability and generating the soil map. Twenty two profiles covering all physiographic units were exposed and studied for morphological properties (Soil Survey Division Staff 2000). Representative soil samples from each horizon of all the pedons were collected for laboratory analysis. Soil clods were collected from the soil horizons for determination bulk density and for aggregate analysis. The analysis of physical, chemical and nutrient properties of collected samples were carried out using standard procedures (Black 1965; Jackson 1967; Lindsay and Norvell 1978). The soils were classified as per Soil Taxonomy (Soil Survey Staff 2003) and grouped under different land capability sub-classes (Klingebiel and Montgomery 1961), land irrigability sub-classes (AIS\&LUS 1971). The soil site suitability analysis (NBSS\&LUP, 1994) was done for evaluating the suitability of different mapping units for paddy, cotton, soybean, sorghum, wheat and chickpea. ArcGIS software was used to generation of various spatial thematic maps.

\section{Results and Discussion}

Present land use/ land cover

Based on image characteristics, the major land use / land cover identified are cultivated land, wasteland with and without scrub, habitation and water bodies (Fig.1a). Cultivated land is again delineated into single and double crop based on temporal data. The extent of area under different land utilization types indicates that cultivated land occupies 83.85 per cent of the total geographical area (TGA) of which 55.44 per cent is under single crop. The area of double crop occupies 28.41 per cent of the cultivated area where assured / protective irrigation is available. Waste land occupies 11.16 per cent of the total geographical 
area, out which 7.88 per cent of waste land is without scrub while 3.28 per cent of waste land is with scrub. Water bodies and habitation occupy 3.38 and 1.61 per cent area, respectively.

\section{Slope}

Four slope classes viz. level to nearly level (0-1\%), very gently sloping (1-3\%), gently sloping (3-8\%) and moderately sloping (8-15\%) lands have been identified (Figlb). The major area is under very gently sloping land (63.96 \% of TGA). Gently sloping, moderately sloping and level to nearly level occupy $15.13,1.24$ and 14.68 per cent of TGA, respectively.

\section{Landform-soil relationship}

Six major landform units viz. isolated mound, subdued plateau, upper pediment, lower pediment, upper plain and lower plain were identified and delineated (Fig.1c). Moderately sloping (8-15\%) isolated mound occur at an elevation of 274 to $272 \mathrm{~m}$ above MSL and support mostly single crop land. The gently sloping (3-8\%) subdued plateau occurs at an elevation 274 to $256 \mathrm{~m}$ above MSL supported also by single crop land. The very gently sloping (1-3\%) pediments according their elevation subdivided into upper pediment occurs at an elevation 269 to $252 \mathrm{~m}$ above MSL lower pediment occur at an elevation 245 to $239 \mathrm{~m}$ above MSL and upper plain land occur at an elevation 260 to $245 \mathrm{~m}$ above MSL mainly supports single and double crop with small area under wasteland with scrub. Similarly level to nearly level (0-1\%) lower plain lands occur at an elevation 235 to $225 \mathrm{~m}$ above MSL supports mostly double crop with few scattered orchards.

Seven soil series (Pohe-1, Pohe-2, Pohe-3, Pohe-4, Shegaon-1, Shegaon-2 and Shegaon-3) were tentatively identified and mapped as soil series and complex with phases at 1: 12500 scales (Fig1d) after establishment of landform-soil relationship (Table1).

\section{Physical and chemical properties of soils}

The clay content of soil varied from 38.0 to 59.9 per cent (Shegaon-3 series). The soils of isolated mound (Pohe-1) and lower pediment (Shegaon-1) are neutral in reaction whereas the soils subdued plateau (Pohe-3), upper pediment (Pohe-4) are slightly alkaline while soils of upper plain (Shegaon-2) and lower plain (Shegaon-3) are strongly alkaline in nature. The organic carbon in surface soils of area ranged from $4.32 \mathrm{~g} \mathrm{~kg}^{-1}$ in soils (Pohe-1) of isolated mound to $8.46 \mathrm{~g} \mathrm{~kg}^{-1}$ in soils of subdued plateau (Pohe-2). In general all these soils are highly base saturated soils. The exchangeable sodium content ranged from 0.8 to $7.54 \mathrm{cmol}(\mathrm{p}+) \mathrm{kg}^{-1}$ in sub-surface horizons of Shegaon-3 soils which is indicative of development of sub-soil sodicity, which is also reflected in the increased 
Table 1. Soil Map legend

\begin{tabular}{|c|c|c|c|c|c|}
\hline $\begin{array}{l}\text { Sr. } \\
\text { No. }\end{array}$ & Landform & $\begin{array}{c}\text { Soil Series \& its } \\
\text { complex }\end{array}$ & Soil Characteristics & Soil Taxon & omy \\
\hline 1. & $\begin{array}{l}\text { Isolated } \\
\text { Mound }\end{array}$ & Pohe-1 & $\begin{array}{l}\text { Very shallow, well drained, non- } \\
\text { calcareous, very dark greyish brown, } \\
\text { (10YR 3/2), clay soils with moderate } \\
\text { erosion. }\end{array}$ & $\begin{array}{l}\text { Fine, smectitic, } \\
\text { hyperthermic } \\
\text { Ustorthent }\end{array}$ & Typic \\
\hline 2. & $\begin{array}{l}\text { Subdued } \\
\text { plateau }\end{array}$ & Pohe-2+Pohe-3 & $\begin{array}{l}\text { Shallow, well drained, non-calcareous, } \\
\text { very dark greyish brown, }(10 \mathrm{YR} 3 / 2) \text {, } \\
\text { clay-skeletal soils with moderate erosion } \\
\text { in complex with, } \\
\text { Well drained, non-calcareous, very dark } \\
\text { greyish brown (10YR } 3 / 2 \mathrm{M}) \text { and clay- } \\
\text { loam to clay soils with moderate erosion. }\end{array}$ & \multicolumn{2}{|c|}{$\begin{array}{l}\text { Clayey-skeletal, } \\
\text { smectitic,hyperthermic } \\
\text { Lithic Haplustept }\end{array}$} \\
\hline 3. & $\begin{array}{l}\text { Upper } \\
\text { pediment }\end{array}$ & $\begin{array}{l}\text { Pohe- } \\
\text { 4+Shegaon-1 }\end{array}$ & $\begin{array}{l}\text { Deep, moderately well drained, non- } \\
\text { calcareous,dark brown (10YR } 3 / 3) \text { clay } \\
\text { soils with slight erosion in complex with; } \\
\text { Deep to very deep, moderately well } \\
\text { drained, non-calcareous,dark greyish } \\
\text { brown (10YR 4/3) clay soils with slight } \\
\text { erosion }\end{array}$ & \multicolumn{2}{|c|}{$\begin{array}{l}\text { Fine, smectitic, } \\
\text { hyperthermic, Vertic } \\
\text { Haplustept }\end{array}$} \\
\hline 4. & $\begin{array}{l}\text { Lower } \\
\text { pediment }\end{array}$ & Shegaon-1 & $\begin{array}{l}\text { Deep to very deep, moderately well } \\
\text { drained, non-calcareous,dark greyish } \\
\text { brown (10YR 4/3) clay soils with slight } \\
\text { erosion }\end{array}$ & $\begin{array}{l}\text { Fine, smectitic, } \\
\text { hyperthermic } \\
\text { Haplustert }\end{array}$ & Typic \\
\hline \multirow[t]{2}{*}{5.} & \multirow[t]{2}{*}{ Upper plain } & \multirow[t]{2}{*}{$\begin{array}{l}\text { Pohe- } \\
3+\text { Shegaon-2 }\end{array}$} & $\begin{array}{l}\text { well drained, non-calcareous, very dark } \\
\text { greyish brown }(10 \mathrm{YR} 3 / 2 \mathrm{M}) \text { and clay- } \\
\text { loam to clay soils with moderate erosion } \\
\text { in complex with; } \\
\text { Deep, moderately well drained, } \\
\text { calcareous, very dark greyish brown }\end{array}$ & \multicolumn{2}{|c|}{$\begin{array}{l}\text { Clayey, smectitic, } \\
\text { hyperthemic Typic } \\
\text { Haplustept }\end{array}$} \\
\hline & & & (10YR 3/2), fine soils with slight erosion & $\begin{array}{l}\text { hyperthermic } \\
\text { Haplustert }\end{array}$ & Typic \\
\hline \multirow[t]{2}{*}{6.} & \multirow[t]{2}{*}{ Lower plain } & \multirow[t]{2}{*}{$\begin{array}{l}\text { Shegaon- } \\
2+\text { Shegaon-3 }\end{array}$} & $\begin{array}{l}\text { Deep, moderately well drained, } \\
\text { calcareous, very dark greyish brown } \\
(10 \text { YR } 3 / 2) \text {, fine soils with slight erosion, } \\
\text { in complex with }\end{array}$ & $\begin{array}{l}\text { Fine, smectitic, }(C \\
\text { hyperthermic, } \\
\text { Haplustert }\end{array}$ & $\begin{array}{l}\text { Calcareous) } \\
\text { Typic }\end{array}$ \\
\hline & & & $\begin{array}{l}\text { Very Deep, imperviously drained, very } \\
\text { dark greyish brown (10YR 3/2), fine soil } \\
\text { with slight erosion }\end{array}$ & $\begin{array}{l}\text { Fine, smectitic, } \\
\text { hyperthermic } \\
\text { Haplustert }\end{array}$ & Sodic \\
\hline
\end{tabular}

$\mathrm{pH}$ and ESP and decrease in saturated hydraulic conductivity of these soils. The cation exchange capacity of soils of watershed varied from $32.29 \mathrm{cmol}(\mathrm{p}+) \mathrm{kg}^{-1}$ in soils of Pohe-1 to $51.65 \mathrm{cmol}(\mathrm{p}+) \mathrm{kg}^{-1}$ in soils of Shegaon-3 soil series. Relatively higher CEC values have been observed in the soils of lower plain region could be attributed to high clay content with smectitic mineralogy (Pal and Deshpande 1987). 


\section{Soil fertility}

The nitrogen content in soils ranged from 57.58 (Shegaon-3) to $287.88 \mathrm{~kg} \mathrm{ha}^{-1}$ (Pohe3) and decreased with depth. Phosphorus content varied between 3.33 (Pohe-2) to $16.35 \mathrm{~kg}$ $\mathrm{ha}^{-1}$ (Pohe-3) and decreased with depth in all soils. Available potassium content in the soils of watershed varied from $250.88 \mathrm{~kg} \mathrm{ha}^{-1}$ to $605.25 \mathrm{~kg} \mathrm{ha}^{-1}$ owing to K-rich minerals occurring in these soil (Pal 1985).

The DTPA- Fe, Mn, $\mathrm{Cu}$ and $\mathrm{Zn}$ of the soils (Table 3) indicated that the DTPA- Fe ranged from 0.84 to $10.24 \mathrm{mg} \mathrm{kg}^{-1}$ the critical value of DTPA- Fe is $4.5 \mathrm{mg} \mathrm{kg}^{-1}$ (Lindsay and Norvell 1978). The DTPA- Mn ranged from 5.2 to $24.72 \mathrm{mg} \mathrm{kg}^{-1}$ above the critical limit 3.0 $\mathrm{mg} \mathrm{kg}^{-1}$ (Takkar et al. 1989). DTPA-Cu varied from 0.7 to $2.35 \mathrm{mg} \mathrm{kg}^{-1}$ was higher than the critical value of $0.2 \mathrm{mg} \mathrm{kg}^{-1}$ (Katyal and Randhawa 1983). The DTPA-Zn ranged from 0.18 to $0.48 \mathrm{mg} \mathrm{kg}^{-1}$ and was found deficient below critical level of $0.6 \mathrm{mg} \mathrm{kg}^{-1}$ as suggested by Katyal and Randhawa (1983). The micronutrient contents in general decreased with depth. 


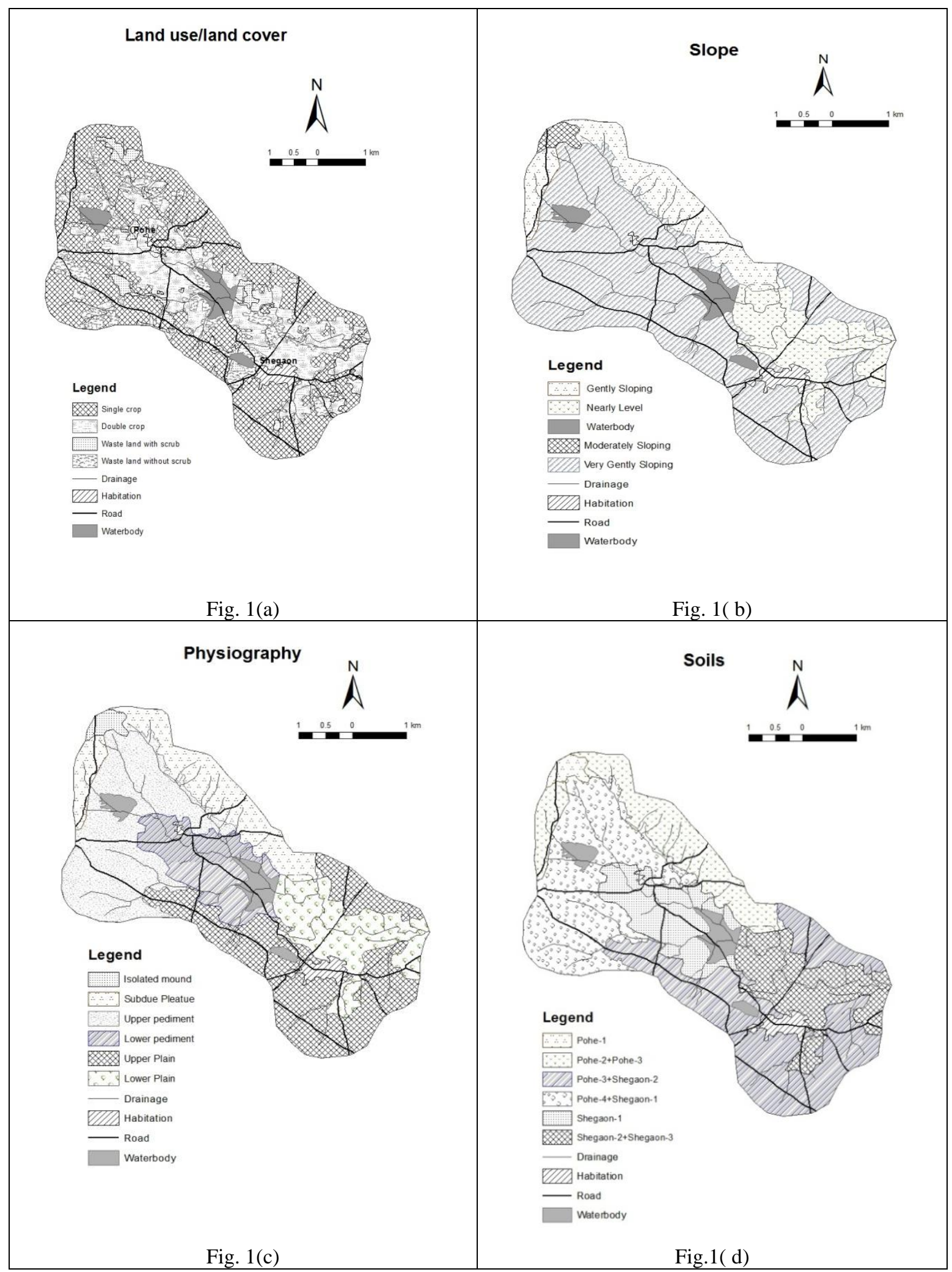

Fig1. Characterization of land use/land cover (a), slope (b), physiography (c) and soils (d) 
Table2. Physical properties of soils

\begin{tabular}{|c|c|c|c|c|c|c|c|c|c|c|}
\hline \multirow{2}{*}{ Horizon } & \multirow{2}{*}{$\begin{array}{c}\text { Depth } \\
\text { (cm) }\end{array}$} & \multirow[t]{2}{*}{ Sand } & \multirow{2}{*}{$\begin{array}{l}\text { Silt } \\
\%\end{array}$} & \multirow[t]{2}{*}{ Clay } & \multirow{2}{*}{$\begin{array}{c}\text { BD } \\
\left(\mathrm{Mg} \mathrm{m}^{-3}\right)\end{array}$} & \multirow{2}{*}{ 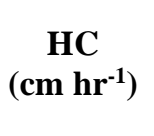 } & \multirow{2}{*}{$\begin{array}{c}\text { MWD } \\
(\mathbf{m m})\end{array}$} & \multicolumn{3}{|c|}{ Water retention (\%) } \\
\hline & & & & & & & & $\begin{array}{c}33 \\
\mathbf{k P a}\end{array}$ & $\begin{array}{l}1500 \\
\mathrm{kPa}\end{array}$ & AWC \\
\hline & & & & & & & & & & \\
\hline Ap & $0-20$ & 24.6 & 34.5 & 40.7 & 1.5 & 2.5 & 0.7 & 32.4 & 20.2 & 12.2 \\
\hline
\end{tabular}

Pedon- 2 (Subdued plateau) Pohe-2: Clayey-skeletal, smectitic, hyperthermic Lithic Haplustept

$\begin{array}{lcccccccccc}\text { Ap } & 0-18 & 17.5 & 39.0 & 43.4 & 1.56 & 2.3 & 0.6 & 29.2 & 15.1 & 14.1 \\ \text { Bw } & 18-32 & 14.8 & 36.2 & 48.9 & 1.5 & 2.6 & 0.6 & 33.7 & 18.9 & 14.8\end{array}$

Pedon-3 (Subdued plateau) Pohe-3 : Clayey, smectitic hyperthermic Typic Haplustept

$\begin{array}{ccccccccccc}\text { Ap } & 0-20 & 31.0 & 30.9 & 38.0 & 1.5 & 2.2 & 0.7 & 36.5 & 27.0 & 9.4 \\ \text { Bw1 } & 20-60 & 26.5 & 34.1 & 39.3 & 1.5 & 2.4 & 0.7 & 35.2 & 23.6 & 11.6 \\ \text { Bw2 } & 60-83 & 21.8 & 36.1 & 41.9 & 1.6 & 2.0 & 0.7 & 37.6 & 24.8 & 12.8\end{array}$

Pedon-4 (Upper pediment) Pohe-4: Fine,smectitic,hyperthermic Vertic Haplustept

$\begin{array}{ccccccccccc}\text { Ap } & 0-20 & 19.4 & 31.6 & 48.9 & 1.4 & 2.5 & 0.7 & 33.1 & 21.3 & 11.8 \\ \text { Bw1 } & 20-52 & 14.2 & 34.1 & 51.6 & 1.5 & 2.1 & 0.7 & 32.5 & 20.3 & 12.2 \\ \text { Bw2 } & 52-89 & 10.3 & 32.6 & 57.0 & 1.5 & 1.9 & 0.7 & 39.8 & 26.9 & 12.8 \\ \text { Bw3 } & 89-122 & 10.6 & 29.5 & 59.7 & 1.5 & 1.9 & 0.7 & 34.6 & 21.2 & 13.4\end{array}$

Pedon-5 (Lower pediment)Shegaon-1: Fine,smectitic,hyperthermic Typic Haplustert

$\begin{array}{ccccccccccc}\text { Ap } & 0-18 & 31.0 & 26.8 & 42.1 & 1.4 & 2.4 & 0.8 & 34.1 & 22.1 & 11.9 \\ \text { Bw } & 18-42 & 27.0 & 28.1 & 44.8 & 1.4 & 2.0 & 0.8 & 34.5 & 20.3 & 14.2 \\ \text { Bss1 } & 42-81 & 25.0 & 27.4 & 47.5 & 1.5 & 2.0 & 0.8 & 36.4 & 21.1 & 15.2 \\ \text { Bss2 } & 81-118 & 21.6 & 29.4 & 48.9 & 1.5 & 1.6 & 0.8 & 41.5 & 24.7 & 16.7 \\ \text { Bss3 } & 118-150 & 19.6 & 30.0 & 50.2 & 1.5 & 1.2 & 0.7 & 47.9 & 29.9 & 18.0\end{array}$

Pedon-6 (Upper plain)Shegaon-2 : Fine (Calcareous),smectitic,hyperthermic Typic Haplustert

$\begin{array}{ccccccccccc}\text { Ap } & 0-19 & 28.1 & 33.8 & 38.0 & 1.5 & 2.2 & 0.7 & 28.8 & 17.6 & 11.2 \\ \text { Bw } & 19-42 & 25.5 & 31.0 & 43.4 & 1.5 & 2.1 & 1.8 & 31.0 & 17.7 & 13.3 \\ \text { Bss1 } & 42-82 & 25.0 & 28.7 & 46.1 & 1.6 & 1.4 & 0.8 & 33.1 & 19.1 & 13.9 \\ \text { Bss2 } & 82-125 & 23.1 & 27.9 & 48.9 & 1.6 & 1.4 & 0.8 & 38.8 & 22.0 & 14.8\end{array}$

Pedon-7 (Lower plain) Shegaon-3: Fine, smectitic hyperthermic Sodic Haplustert

\begin{tabular}{ccccccccccc} 
Ap & $0-17$ & 21.7 & 32.5 & 45.6 & 1.6 & 2.4 & 0.7 & 28.0 & 14.7 & 13.2 \\
Bw & $17-54$ & 19.4 & 31.6 & 48.9 & 1.7 & 2.3 & 0.7 & 30.9 & 17.3 & 13.6 \\
Bss1 & $54-85$ & 19.0 & 34.0 & 46.9 & 1.8 & 1.6 & 0.7 & 30.5 & 12.0 & 18.4 \\
Bss2 & $85-120$ & 8.8 & 32.4 & 58.6 & 1.7 & 0.6 & 0.7 & 32.8 & 13.4 & 19.3 \\
Bss3 & $12-150$ & 8.1 & 31.8 & 59.9 & 1.8 & 0.2 & 0.7 & 36.2 & 16.2 & 20.0 \\
\hline
\end{tabular}


Table 3. Chemical and nutrient properties of soils

\begin{tabular}{|c|c|c|c|c|c|c|c|c|c|c|c|}
\hline \multirow[t]{2}{*}{ Horizon } & \multirow[t]{2}{*}{$\begin{array}{c}\text { Depth } \\
(\mathrm{cm})\end{array}$} & \multirow[t]{2}{*}{$\underset{(1: 2.5)}{\text { pH }}$} & \multirow[t]{2}{*}{$\begin{array}{c}\text { EC } \\
(1: 2.5)\end{array}$} & \multirow[t]{2}{*}{$\begin{array}{c}\text { O.C. } \\
(\mathrm{g} / \mathrm{kg})\end{array}$} & \multirow[t]{2}{*}{$\begin{array}{l}\mathrm{CaCO}_{3} \\
(\%)\end{array}$} & \multirow[t]{2}{*}{$\begin{array}{c}\mathrm{CEC} \\
\operatorname{cmol}^{\left(\mathbf{p}^{+}\right)} \\
\mathbf{k g}^{-1}\end{array}$} & \multirow{2}{*}{$\begin{array}{l}\text { BS } \\
(\%)\end{array}$} & \multicolumn{4}{|c|}{$\begin{array}{l}\text { Available micronutrients } \\
\qquad\left(\mathrm{mg} \mathrm{kg}^{-1}\right)\end{array}$} \\
\hline & & & & & & & & $\mathbf{C u}$ & $\mathbf{F e}$ & $\mathbf{Z n}$ & Mn \\
\hline \multicolumn{12}{|c|}{ Pedon- 1 (Isolated mound) Pohe-1: Fine, smectitic, hyperthermic Typic Ustrothent } \\
\hline Ap & $0-20$ & 7.6 & 0.4 & 4.3 & 1.3 & 32.2 & 99.1 & 0.7 & 4.6 & 0.3 & 16.4 \\
\hline
\end{tabular}

Pedon- 2 (Subdued plateau) Pohe-2: Clayey-skeletal, smectitic, hyperthermic Lithic Haplustept

$\begin{array}{llllllllllll}\text { Ap } & 0-18 & 7.5 & 0.3 & 8.4 & 7.1 & 33.7 & 96.7 & 2.3 & 5.1 & 0.4 & 20.4 \\ \text { Bw } & 18-32 & 7.6 & 0.6 & 6.4 & 3.8 & 33.9 & 97.5 & 1.6 & 4.7 & 0.4 & 16.5\end{array}$

Pedon-3 (Subdued plateau) Pohe-3 : Clayey, smectitichyperthermic Typic Haplustept

$\begin{array}{cccccccccccc}\text { Ap } & 0-20 & 8.0 & 0.1 & 7.9 & 0.8 & 32.9 & 95.6 & 0.8 & 6.1 & 0.4 & 10.0 \\ \text { Bw1 } & 20-60 & 8.1 & 0.1 & 5.2 & 1.2 & 35.2 & 93.9 & 0.8 & 5.7 & 0.3 & 7.5 \\ \text { Bw2 } & 60-83 & 8.1 & 0.1 & 3.6 & 2.2 & 37.8 & 92.8 & 0.8 & 5.0 & 0.3 & 5.2\end{array}$

Pedon-4 (Upper pediment) Pohe-4: Fine,smectitic,hyperthermic Vertic Haplustept

$\begin{array}{cccccccccccc}\text { Ap } & 0-12 & 8.0 & 0.1 & 5.3 & 0.8 & 36.8 & 95.5 & 1.0 & 6.1 & 0.3 & 14.1 \\ \text { Bw1 } & 12-42 & 8.1 & 0.1 & 4.1 & 2.2 & 36.0 & 96.5 & 0.8 & 5.3 & 0.2 & 11.3 \\ \text { Bw2 } & 42-88 & 8.1 & 0.2 & 2.7 & 4.1 & 37.8 & 94.8 & 0.8 & 5.0 & 0.2 & 10.4 \\ \text { Bw3 } & 88-122 & 8.2 & 0.2 & 2.9 & 1.5 & 38.9 & 92.9 & 0.6 & 4.9 & 0.1 & 8.9\end{array}$

Pedon-5 (Lower pedment)Shegaon-1: Fine,smectitic,hyperthermic Typic Haplustert

$\begin{array}{cccccccccccc}\text { Ap } & 0-18 & 7.0 & 0.1 & 5.7 & 2.5 & 37.7 & 95.6 & 1.8 & 7.1 & 0.4 & 24.7 \\ \text { Bw1 } & 18-42 & 7.2 & 0.1 & 3.8 & 3.3 & 38.3 & 93.9 & 1.1 & 6.4 & 0.4 & 22.8 \\ \text { Bw2 } & 42-81 & 7.5 & 0.1 & 3.1 & 2.1 & 39.1 & 93.0 & 1.0 & 5.5 & 0.3 & 13.7 \\ \text { Bss1 } & 81-118 & 7.4 & 0.1 & 2.5 & 3.8 & 39.6 & 92.3 & 0.9 & 5.0 & 0.3 & 15.1 \\ \text { Bss2 } & 118-150 & 7.5 & 0.2 & 3.1 & 4.5 & 40.2 & 90.9 & 1.3 & 4.8 & 0.3 & 16.3\end{array}$

Pedon-6 (Upper plain)Shegaon-2 :Fine (Calcareous),smectitic,hyperthermic Typic Haplustert

$\begin{array}{cccccccccccc}\text { Ap } & 0-19 & 7.8 & 0.3 & 6.8 & 4.5 & 35.6 & 91.0 & 1.5 & 10.2 & 0.3 & 21.3 \\ \text { Bw } & 19-42 & 8.2 & 0.3 & 2.6 & 5.8 & 38.0 & 88.0 & 1.0 & 8.2 & 0.3 & 12.7 \\ \text { Bss1 } & 42-82 & 8.3 & 0.2 & 2.1 & 9.4 & 41.2 & 89.4 & 1.1 & 6.2 & 0.3 & 11.5 \\ \text { Bss2 } & 82-125 & 8.5 & 0.3 & 1.0 & 15.7 & 44.6 & 87.4 & 0.9 & 6.1 & 0.3 & 13.2\end{array}$

Pedon-7 (Lower plain) Shegaon-3:Fine,smectitic hyperthermic SodicHaplustert

\begin{tabular}{cccccccccccc} 
Ap & $0-17$ & 8.0 & 0.1 & 5.7 & 6.1 & 32.3 & 95.5 & 1.0 & 4.4 & 0.4 & 11.6 \\
Bw & $17-54$ & 8.3 & 0.1 & 5.3 & 5.7 & 35.3 & 93.9 & 1.0 & 4.3 & 0.3 & 9.5 \\
Bss1 & $54-85$ & 8.8 & 0.1 & 4.9 & 7.8 & 37.4 & 93.5 & 1.0 & 3.8 & 0.4 & 8.4 \\
Bss2 & $85-120$ & 8.9 & 0.3 & 4.5 & 11.2 & 39.6 & 93.0 & 0.9 & 3.6 & 0.4 & 7.0 \\
Bss3 & $120-150$ & 9.0 & 0.7 & 4.4 & 14.8 & 42.4 & 89.9 & 0.9 & 3.0 & 0.4 & 6.4 \\
\hline
\end{tabular}




\section{Land capability and irrigability classification}

According to land capability classification soils were grouped under four land capability classes and five subclasses (IIIsf, IIIst, IVs, Vs, VIs) and indicated that most of the area of the watershed were suitable for agriculture. Pohe-1 soils have land capability subclasses VIs due to depth limitation, mostly recommended for agroforestry. Pohe-2 soils also have depth constraint (IVs) mostly cultivated for single crops. Soils of Shegaon-2 and Shegaon-3 series have sub-surface compaction owing to higher ESP which can be used for the cultivation of shallow rooted crops or after other crops under suitable agro-managements. Pohe-3, Pohe-4 and Shegaon-1 soils may be cultivated to climatically adopted varieties of crops.

The soils were grouped into 2s, 2st, 3st and 4s land irrigability subclasses, and nearly 98.73 per cent area of the watershed is fit for irrigation. The soil-site suitability evaluation indicated that the soils of isolated mound (Pohe-1) were potentially suitable for cultivation of crops because of limitation posed by slope and soil depth. The soils of subdued plateau (Pohe2 and Pohe-3) are marginally (S3) to moderately (S2) suitable for paddy, cotton, sorghum, pigeonpea, chickpea and wheat. The soil series (Pohe-4, Shegaon-1, Shegaon-2 and Shegaon-3) were found to be marginally to moderately suitable for all crops whereas the lower plain soils (Shegaon-3) have potentially suitable (N1) for paddy and pigeonpea due to sub-surface sodicity. Shegaon-1 soils were highly suitable for sorghum and pigeonpea. 


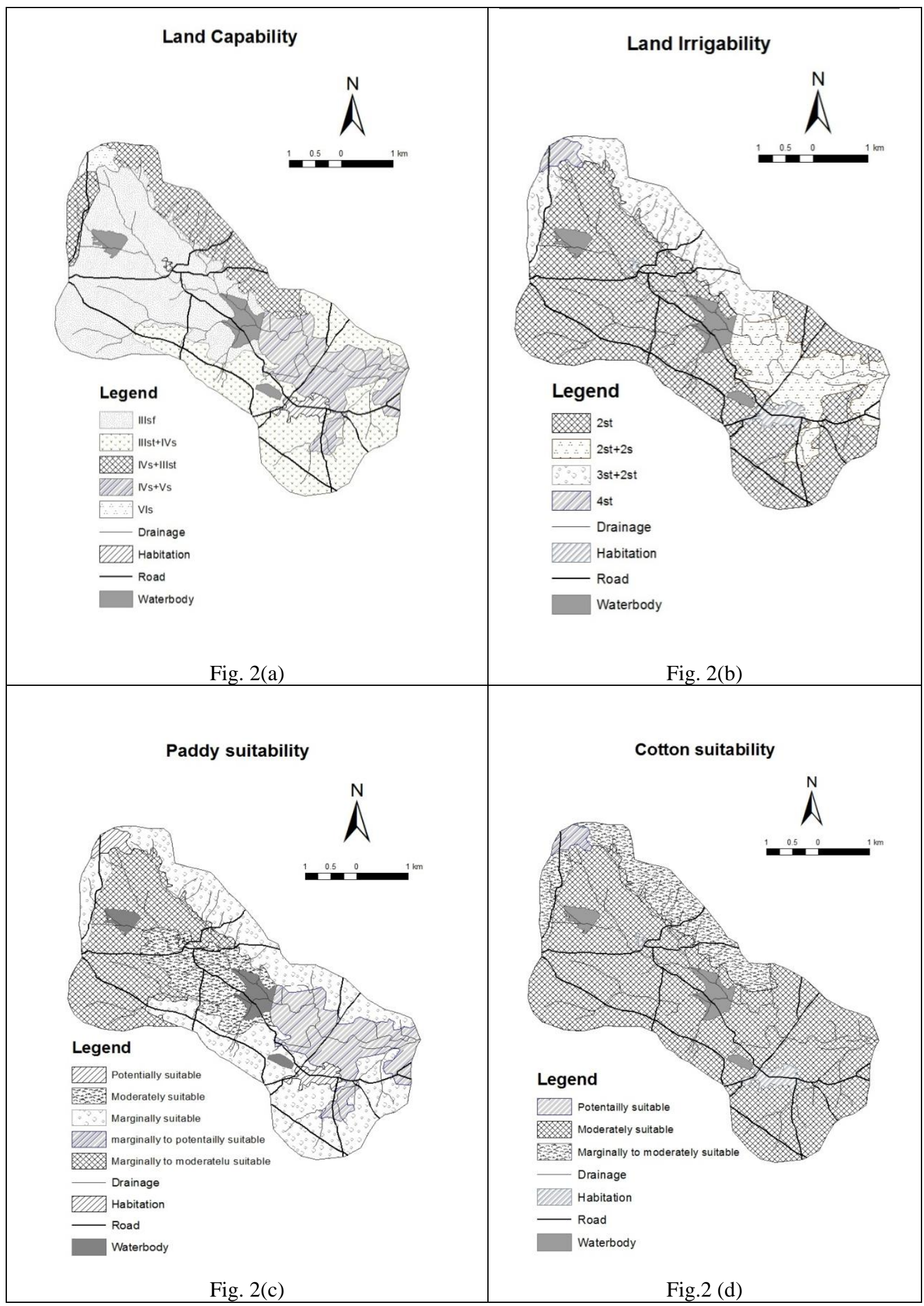

Fig. 2. Land evaluation maps for capability (a), irrigability (b), suitability for paddy(c) and cotton (d) 


\section{Conclusions}

The characterization of soil properties using geo-statistics revealed that the soils are very low to low in available nitrogen, phosphorus and high in potassium content with acute deficiency of available zinc. The soil-site suitability assesses the suitability of land for various uses relevant to the areas and subsequently for making land use recommendations. The soils of watershed are potentially to highly suitable for cultivation of paddy, cotton, pigeonpea, soybean, sorghum, wheat and chickpea crops having the constraints of inadequate soil depth and higher slope at isolated mound and subdued plateau, less organic matter, subsurface sodicity and higher bulk density at lower plains. The suggested land use plan generated on the basis of various limitations will help in achieving the potential yields on a sustainable basis for similar soils under similar agroclimatic conditions elsewhere.

\section{References}

AIS\&LUS (1971). Soil Survey Manual, All India Soil and Land Use survey (AIS \& LUS) publication, IARI, New Delhi; 121 p.

Black C.A. (1965). Methods of Soil Analysis, Part I\&2 American Society of Agronomy, Madison, Wisconsin USA.

FAO, (1976). A Frame Work for Land Evaluation, Soil Bulletin No. 32, FAO, Rome.

Jackson M.L., (1967). Soil Chemical Analysis, Prentice Hall India Pvt. Ltd., New Delhi.

Katyal J.C. and Randhawa N.S. (1983). Secondary micronutrients: Research gaps and future needs. In Micronutrients. FAO Fertilizer and Plantation bulletin, Rome 5, p-92.

Kasturirangan K., Aravamundam R., Deekshatulu B.L., George Joseph and Chandrashekhar M.G. 1996. Indian Remote Sensing Satellite IRS IC. The beginning of new era, Current Science. 70,495-500.

Klingebiel A.A and Montgomery P.H., (1961). Land Capability Classification, Agriculture Handbook 210, Soil Conservation Service, USDA. Washington, D. C.: 105-108.

Lillesand T.M. and Kiefer R.W. (2002). Remote Sensing and Image Interpretation. (John Wiley, Singapore).

Lindsay W.L. and Norvell W.A., (1978). Development of DTPA soil test zinc, iron, manganese and copper. Soil Science Society of America Journal 42, 421-448.

NBSS\&LUP 1994.Soil-site suitability criteria for different crops. In: Proceedings of National Meet on soil- site suitability criteria for different crops. Feb. 7-8, 31. (Restricted to few crops see other publication of Bureau Naidu et al.) 
Pal D.K. and Deshpande S.B., (1987). Characteristics and genesis of minerals in some benchmark Vertisols of Southern India. Pedologie 37, 235-248.

Sehgal J.L. (1996). Pedology: Concepts and Applications, Kalyani Publishers, New Delhi.

Sharma B.D.S. Mukhopadhaya and P.S.Sidhu (1999). Micro-topographic control on formation in the Punjab region, India, Geoderma 81, 357-368.

Shukla E.A., Jagdish Prasad, Nagaraju M.S.S., Srivastava R, and Kauraw D.L. (2009). Use of Remote Sensing in Characterization and Management of Dhamni Micro-watershed of Chandrapur District of Maharashtra Journal of the Indian Society of Remote Sensing 37, 129-137.

Soil Survey Division Staff (2000). Soil survey Manual. Handbook 18. (USDA Washington, DC)

Soil Survey Division Staff, (2003). Keys to Soil Taxonomy, $9^{\text {th }}$ Edition, USDA, NRCS: Washington, D.C.

Srivastava R. and. Saxena R.K., (2004). Techniques of large scale soil mapping in basaltic terrain using satellite remote sensing data. International Journal of Remote Sensing. 25, 679-688.

Takkar P.N., Chhibha L.M. and Mehta S. K. (1989). Twenty years of coordinated research on micronutrient in soil and plant. Bulletin, Indian Institute of Soil Science, Bhopal. $75 \mathrm{p}$.

Venkatratnam L. (1981). Delineation and mapping of problem soils with remotely sensed data. In Application of Remote sensing for rice production, Hyderabad, Andhra Pradesh. 